\title{
Традиции ведения хлебных заквасок на Русском Севере
}

\section{В.К. Хлесткин 凶}

\begin{abstract}
Аннотация: Сотрудниками Санкт-Петербургского филиала Научно-исследовательского института хлебопекарной промышленности летом 2019 г. была организована экспедиция с целью поиска новых образцов хлебных заквасок. Предполагалось, что в географически удаленных и частично изолированных местах при постоянном ведении (воспроизведении и поддержании в жизнеспособном состоянии) хлебных заквасок в течение длительного периода времени возможна определенная селекция уникальных микробных сообществ, населяющих крахмально-белковую матрицу. При этом состав этого микробного сообщества определяется локальными условиями: качеством и биохимическим составом воды и муки, температурным режимом процессов и окружающей микробиологической обстановкой. Таким образом, в удаленных населенных пунктах, монастырях и подворьях Русского Севера представлялось возможным найти новые микроорганизмы для охарактеризации и дальнейшего изучения с целью расширить коллекцию хлебопекарных микроорганизмов и возможностей их промышленного применения. Экспедиция пересекла четыре региона: Ленинградскую, Архангельскую и Вологодскую области и Карелию - в течение 12 дней. Длина пройденного пути составила около 2500 км. В результате проведенной работы установлено, что местные жители и служители монастырей считают целесообразным ведение закваски лишь тогда, когда есть достаточное количество потребителей хлеба на закваске (50 человек и более). Кроме того, в ряде случаев хозяйства перешли на применение промышленных методик и полуфабрикатов, не утруждаясь сохранением традиционных рецептур. В ходе экспедиции получены четыре аутентичные ржаные закваски и две пшеничные. Микробиологические исследования показали, что в основном в состав микробиологического сообщества закваски входят молочнокислые бактерии не только широко известного в отечественном хлебопечении рода Lactobacillus, но также родов Weissella и Pediococcus и дрожжи из семейства Saccharomycetaceae.
\end{abstract}

Ключевые слова: закваски; лактобактерии; хлебопечение; микробное сообщество; хлеб; экспедиция; Русский Север;

монастырь.

Благодарности: Работа по сбору материала и исследованию микробиома заквасок проводится при поддержке Российского фонда фундаментальных исследований (проект № 19-016-00085). Автор также выражает благодарность сотрудникам ВИРа Ирене Георгиевне Чухиной и Лилии Юрьевне Шипилиной за составление маршрута экспедиции, поддержку и крепкий командный дух, а также водителю Алексею Владимировичу Ухатову за надежность и стойкость перед лицом экспедиционных невзгод.

Для цитирования: Хлесткин В.К. Традиции ведения хлебных заквасок на Русском Севере. Письма в Вавиловский журнал генетики и селекчии. 2020;6(2):65-71. DOI 10.18699/Letters2020-6-08

\section{Traditions of local bread sourdoughs management on the Russian North}

\section{V.K. Khlestkin $\bowtie$}

Abstract: The article was written in the wake of the expedition undertaken by employees of the Saint-Petersburg Brunch of Federal State Autonomous Scientific Institution "Scientific Research Institute for the Baking Industry" in the summer of 2019 in order to search for new samples of bread starter cultures. It was assumed that in geographically remote and more or less isolated places with the constant «management» (reproduction and maintenance) of starter cultures for a long period of time, a certain selection of the microbial community inhabiting the starch-protein matrix is possible. At the same time, the composition of this microbial community is determined by local conditions: the quality and biochemical composition of water and flour, and the temperature regime of the processes. Thus, in remote settlements, monasteries and courtyards of the Russian North, it was possible to find new microorganisms

Всероссийский научно-исследовательский институт генетики и разведения сельскохозяйственных животных - филиал Всероссийского научно-исследовательского института животноводства имени академика Л.К. Эрнста, Санкт-Петербург, Пушкин, Россия

Санкт-Петербургский филиал ФГАНУ Научно-исследовательский институт хлебопекарной промышленности, Санкт-Петербург, Россия

Russia Research Institute of Farm Animal Genetics and Breeding - Branch of the L.K. Ernst Federal Science Center for Animal Husbandry,

Saint-Petersburg, Russia

Saint-Petersburg Brunch of Federal State Autonomous Scientific Institution "Scientific Research Institute for the Baking Industry", Saint-Petersburg, Russia

هe-mail: dir2645@yandex.ru

(C) Хлесткин В.К., 2020

Контент доступен под лицензией Creative Commons Attribution 4.0 License 
for characterization and further study in order to expand the collection of baking microorganisms and the possibilities of their industrial application. The expedition crossed four regions: Leningrad, Arkhangelsk and Vologda regions and Karelia for 12 days. The distance traveled was about $2500 \mathrm{~km}$. As a result of the work, it was found that local residents and ministers of the monasteries consider it appropriate to conduct sourdough if there are a sufficient number of consumers of sourdough bread (about 50 people or more). In addition, in some cases, farms switched to the application of industrial methods and semi-finished products, without bothering to preserve traditional recipes. During the expedition, four authentic rye starter cultures and two wheat starter cultures were obtained. Microbiological study of microbial communities of the starters showed that they include lactic acid bacteria not only of the genus Lactobacillus widely known in domestic bakery, but also of the genera Weissella and Pediococcus, as well as yeast from the Saccharomycetaceae family.

Key words: sourdoughs; lactic acid bacteria; bread baking; microbial community; bread; expedition; Russian North; monastery.

Acknowledgements: Collecting material and studying the microbiome of sourdoughs' cultures is supported by the Russian Foundation for Basic Research (project No. 19-016-00085). The author also expresses gratitude to employees of VIR Irena Georgievna Chukhina and Lilia Yurievna Shipilina - for planning the expedition route, support and strong team spirit, and our driver Alexey Vladimirovich Ukhatov for reliability and resilience in the face of expeditionary adversity.

For citation: Khlestkin V.K. Traditions of local bread sourdoughs management on the Russian North. Pisma v Vavilovskii Zhurnal Genetiki i Selektsii = Letters to Vavilov Journal of Genetics and Breeding. 2020;6(2):65-71. DOI 10.18699/Letters2020-6-08 (in Russian)

\section{Введение}

Сообщества микроорганизмов, в частности дрожжей и молочнокислых бактерий, с давних пор целенаправленно используются в приготовлении напитков или пищи. При этом возникают системы связанных сложными взаимоотношениями микроорганизмов, сопровождающимися эффектами доминирования, вытеснения или, наоборот, метаболической поддержки одних микроорганизмов другими. Не является исключением и микробиом хлебных заквасок. Закваску для хлебопекарного производства ГОСТ 32677-2014 определяет как полуфабрикат хлебопекарного производства, полученный сбраживанием питательной смеси молочнокислыми бактериями, или молочнокислыми бактериями и хлебопекарными дрожжами, или другими микроорганиз мами, применяемыми в хлебопекарной промышленности. Хлебобулочные изделия на заквасках характеризуются высокими показателями качества: вкусом, запахом, питательной ценностью и устойчивостью к микробной порче, что приводит к необходимости получать закваски с заданными физико-химическими свойствами и вкусо-ароматическими характеристиками (Афанасьева, 2003; Сборник.., 2008; Viiard et al., 2016; Sieuwerts et al., 2018).

В настоящее время наблюдается ренессанс производства хлеба на заквасках, поиска новых органолептических и технологических свойств хлебобулочных изделий, в связи с чем стал актуальным вопрос поиска новых или хорошо забытых старых микробных сообществ, населяющих закваски. Пекарни хлебозаводов и других производств, расположенных в крупных городах и примыкающих к ним районах, по экономическим соображениям должны поддерживать непрерывное производство хлеба «на потоке». Это означает, что такие предприятия должны отказываться от более сложной технологии производства хлеба на закваске в пользу более простых решений, основанных на использовании дрожжей или коммерческих улучшителей. Те пекарни, которые все же работают с закваской, приобретают давно разработанные и апробированные составы чистых культур заквасочных микроорганизмов, например, из биоресурсной коллекции Санкт-Петербургского филиала ФГАНУ НИИ хлебопекарной промышленности. Поэтому биоразнообра- зие заквасок в крупных населенных пунктах невелико и хорошо известно. Соответственно, появляется задача поиска новых микробных компонентов для новых вкусовых и технических качеств заквасок и хлеба.

Существует вероятность обнаружить новые или уже знакомые, но отсутствующие в коллекции штаммы заквасочных микроорганизмов в удаленных или географически изолированных населенных пунктах. В своем жизненном цикле закваска может претерпевать огромное количество повторяющихся циклов освежения (подкормки водой и мукой) в течение многих месяцев и лет. При этом может происходить естественная селекция микробного сообщества, характерного именно для этой местности и местного качества воды и муки, а также местных погодных условий и традиций хлебопечения. Таким образом, давно ведомые локальные закваски служат потенциальным источником новых штаммов микроорганизмов.

В целях поиска новых перспективных штаммов микроорганизмов (молочнокислых бактерий, дрожжей и других) участниками проекта РФФИ «Исследование видового разнообразия и симбиотических взаимодействий в микробиомах крахмало-белковых гидроколлоидных систем (хлебных заквасок)» была предпринята экспедиция по удаленным малым населенным пунктам (деревням), монастырям и подворьям Русского Севера с целью исследования традиций хлебопечения в этих местах, а также получения образцов местных заквасок для последующего изучения и в случае получения интересных результатов сохранения всего микробиома или отдельных чистых культур микроорганизмов в биоресурсной коллекции Санкт-Петербургского филиала ФГАНУ НИИ хлебопекарной промышленности. Филиал специализируется на научно-прикладных и технологических разработках хлебобулочных изделий на основе ржаной муки, поэтому особый интерес для экспедиции представляли закваски на ржаной муке. По-видимому, это первая официальная экспедиция в регионы Русского Севера, целью которой ставится получение образцов местных хлебных заквасок, поскольку даже в обзорной российской научной литературе нет упоминаний о подобных исследованиях (Афанасьева и др., 2009; Карельская, 2015). 


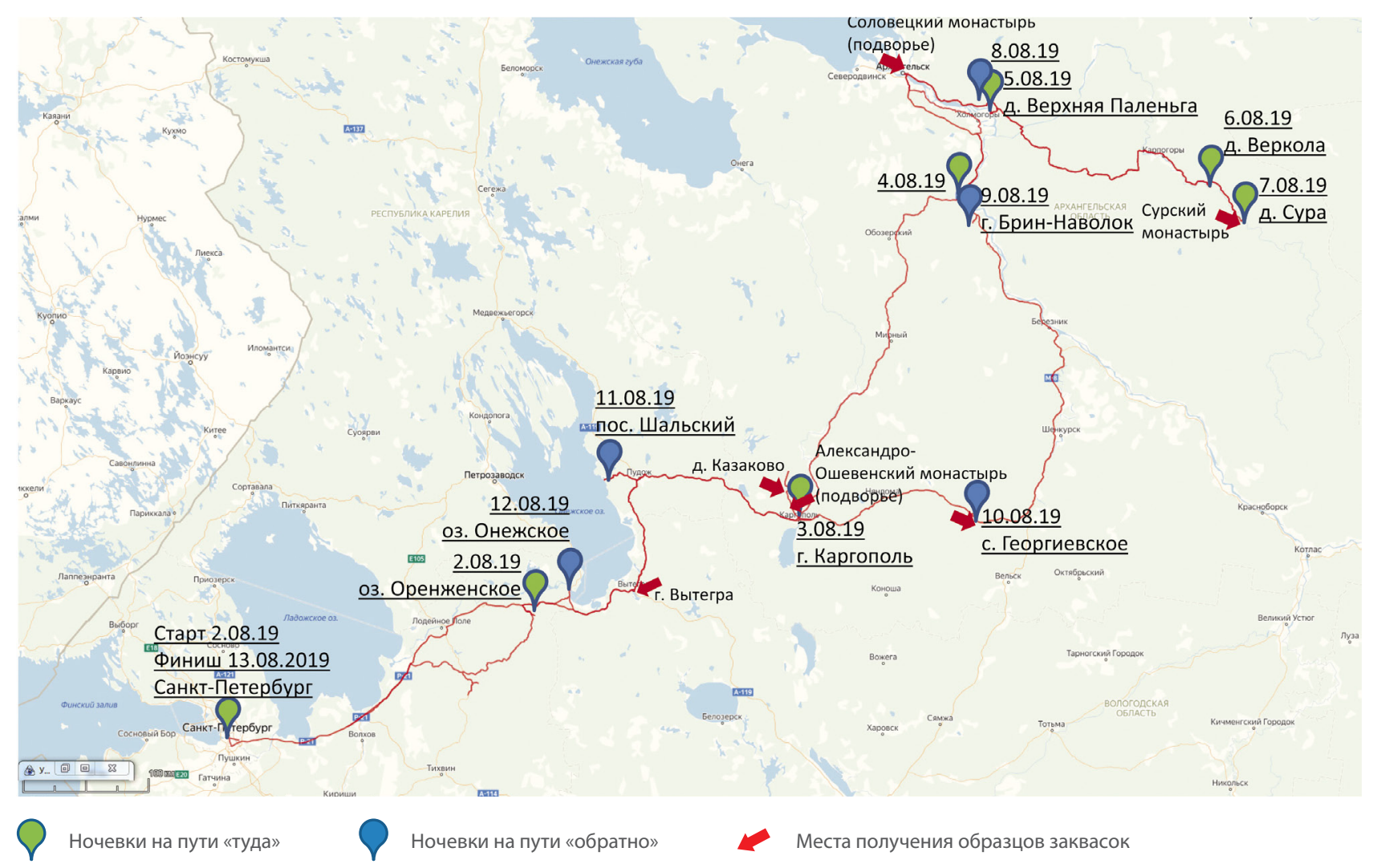

Рис. 1. Карта маршрута экспедиции

Fig. 1. Expedition route map

\section{Материалы и методы}

Экспедиция проходила по четырем регионам: Ленинградской, Архангельской и Вологодской областям и Карелии - в течение 12 суток, со 2 по 13 августа 2019 года. Длина пройденного пути составила около 2500 км. Маршрут был проложен с расчетом посетить наибольшее количество удаленных действующих монастырей в регионе и заходить по пути в населенные пункты (рис. 1). В ходе экспедиции использовали транспортное средство УАЗ «Патриот» без специальной подготовки, прошедшее стандартное техническое обслуживание. Для ночевок разбивали лагерь (рис. 2).

Предполагалось, что собранные образцы могут быть или «живой» постоянно обновляющейся закваской, хранящейся при температуре выше $0{ }^{\circ} \mathrm{C}$, или высохшей субстанцией, остающейся в деревянной посуде (кадушках), которую используют хозяйки при замесе хлебобулочных изделий. «Живую» закваску собирали в полиэтиленовые пакеты или стандартные завинчивающиеся пластиковые баночки с широким горлом. Хранить закваску рекомендуется при температуре $0 \ldots+5{ }^{\circ} \mathrm{C}$. Но, поскольку холодильник в экспедиции не предусмотрен, был разработан экспресс-метод для консервации «живой» закваски между листов бумаги по аналогии с гербарием, с дальнейшим сохранением полученного влажного порошка при комнатной или уличной температуре (+5...+10 $\mathrm{C}$ в это время года). Сухую закваску собирали в полиэтиленовые пакеты.

Таксономический анализ грибного сообщества определяли с помощью секвенирования ампликонных библиотек фрагментов рибосомальных оперонов грибов (ITS2), полученных методом ПЦР с использованием ITS1F/ITS2 праймеров. Таксономический анализ бактериального сообщества проводили с помощью ПЦР с универсальными праймерами F515/R806 на вариабельный участок гена 16SpPHKv3-v4, специфичный для широкого круга микроорганизмов, включая бактерии и археи (Локачук и др., 2019).

\section{Результаты и обсуждение}

В ходе экспедиции значительное внимание было уделено непосредственному контакту с жителями местных деревень и поселков. Порой поиск человека, занимающегося в том или ином населенном пункте выпечкой хлеба на закваске, напоминал приключенческий сюжет или «квест». Как правило, первые опрошенные деревенские жители могли лишь примерно сориентировать, куда лучше отправиться и с кем поговорить, кому позвонить, кто может лучше знать ответы на интересующие вопросы. Затем следовали более прицельные поиски с визитами по указанным адресам и пекарням. Наилучшие результаты приносили наши визиты «на обратном пути». То есть по пути «туда», к конечной цели экспедиции удавалось пройти большую часть поисков, но зачастую оказывалось, что человек (пекарь), которого искали, отсутствует именно в этот день. Тогда на пути «обратно» через несколько дней мы имели шанс заранее договориться о встрече, беседе и в качестве заслуженной награды о передаче образца. Необходимо отметить, что местные жители лояльно относились к членам экспедиции, вполне дру- 
Собранные закваски и преобладающие в них микроорганизмы Collected sourdoughs and prevailing microorganisms

\begin{tabular}{|c|c|c|c|c|}
\hline № & Закваска & Место получения & $\begin{array}{l}\text { Преобладающие молоч- } \\
\text { нокислые бактерии }\end{array}$ & $\begin{array}{l}\text { Преобладающие } \\
\text { дрожжи }\end{array}$ \\
\hline 1 & Ржаная & Хлебопекарное производство, Вытегра & Weissella & Saccharomycetes \\
\hline 2 & Ржаная & $\begin{array}{l}\text { Подворье Александро-Ошевенского монастыря, } \\
\text { Архангельская область, Каргопольский р-н, д. Евсеево }\end{array}$ & Lactobacillus & Saccharomycetes \\
\hline 3 & Ржаная & Подворье Соловецкого монастыря, Архангельск & Lactobacillus & Kazachstania \\
\hline 4 & Ржаная & $\begin{array}{l}\text { Пекарня д. Казаково, Архангельская область, } \\
\text { Каргопольский р-н }\end{array}$ & Lactobacillus & Saccharomycetes \\
\hline 5 & Пшеничная & $\begin{array}{l}\text { Закваска, привезенная с о. Афон, ведомая два года } \\
\text { в Сурском монастыре }\end{array}$ & Lactobacillus & Saccharomycetes \\
\hline 6 & Пшеничная & $\begin{array}{l}\text { Сухая закваска, частное домохозяйство, } \\
\text { с. Георгиевское }\end{array}$ & $\begin{array}{l}\text { Lactobacillus } \\
\text { pediococcus }\end{array}$ & Saccharomycetes \\
\hline
\end{tabular}

желюбно поддерживали беседу. Хорошо помогало в беседе знание местной истории и своего предмета - хлебопечения на заквасках.

Отдельно хотелось бы поблагодарить служащих посещенных нами монастырей и подворий за то, что практически всегда со вниманием и пониманием они относились к нашей научной задаче, поскольку она в значительной степени была им не только понятна, но и пересекалась с их задачами - сохранение и поддержание традиционных методов ведения хозяйства с использованием локальных адаптированных элементов биоразнообразия. В некоторых случаях служащие даже выражали желание «делать все по науке» - правильно получать и перерабатывать урожай или печь хлеб.

К сожалению, приходится констатировать, что такая экспедиция была бы значительно более эффективной лет двадцать назад. В настоящее время традиция ведения заквасок в деревнях и поселках практически вытеснена другими технологиями. Много раз нам приходилось слышать, что «Была бабушка пару лет назад, еще вела закваску, а теперь ее уже нет», или «Я раньше вела закваску, а теперь осталась тут одна - мне столько хлеба не надо, мне надолго хватает небольшого купленного куска», «Мы не ведем закваску, потому что приезжаем сюда на несколько дней/недель/месяцев в году». Несколько осложняло и затягивало процесс поисков закваски слабое понимание некоторыми собеседниками сути процесса - так, иногда путали технологию закваски с технологией опары и так далее.

Отчетливо проявилась экономическая составляющая заквасочной технологии: население не видит смысла прибегать к получению хлеба на закваске, когда для продукции нет значительного «рынка сбыта». Закваску ведут в том случае, если есть не менее 50-100 потребителей хлебопекарной продукции на закваске. Как правило, это деревенские пекарни, ведущие закваску сами (например, г. Вытегра, д. Казаково Каргопольского района) или сотрудничающие с частными пекарями (например, д. Пинега), либо монастырские подворья (подворье Соловецкого монастыря в Архан- гельске, подворье Александро-Ошевенского монастыря). Всего в ходе экспедиции мы посетили: Александро-Ошевенский монастырь и его подворье (рис. 3), подворье Соловецкого монастыря, Свято-Иоанно-Богословский монастырь, Артемиево-Веркольский монастырь, Сурский монастырь, Троицкий Антониево-Сийский монастырь, Покрово-Тервенический монастырь и его скит, а также ряд городов и сел, во многих из которых сохранились памятники деревянного зодчества (рис. 4).

Единственным образцом закваски, полученным у местных жителей (не из пекарен и не с подворья монастырей), была пшеничная закваска, которую вели в течение нескольких лет в с. Георгиевском Вельского района Архангельской области, в семье вепсов - представителей финно-угорского народа. На момент нашего визита закваска была высушена, законсервирована и в живом виде не поддерживалась. Собранные нами образцы заквасок переданы на исследование таксономической структуры микробиома (см. таблицу). Более детальное описание результатов можно найти в работе (Локачук и др., 2019). Полученные в ходе экспедиции образцы жидкой закваски необходимо было хранить при пониженной температуре $\left(+5-0{ }^{\circ} \mathrm{C}\right)$ с периодической подкормкой мукой и водой и обновлением.

Погода, как правило, способствовала перевозке живой закваски, температура держалась на уровне около $10{ }^{\circ} \mathrm{C}$, с первыми заморозками по ночам. Тем не менее живая закваска в значительной степени увеличивалась в объеме, и важно было сохранить ее до конца экспедиции. Кроме того, для освежения образцов при сохранении заквасочного микробного сообщества необходима была мука и вода именно из тех мест, где была получена закваска, что делало процесс сохранения и доставки закваски в живом виде практически нереализуемым. Ее можно было бы высушить при комнатной температуре и довезти до лаборатории в сухом виде. Однако все дни экспедиции почти непрерывно шли дожди, и влажность окружающей среды около 100\% не давала шансов высушить закваску обычным способом. Тогда для получения сухой или полусухой закваски без ее значительного 


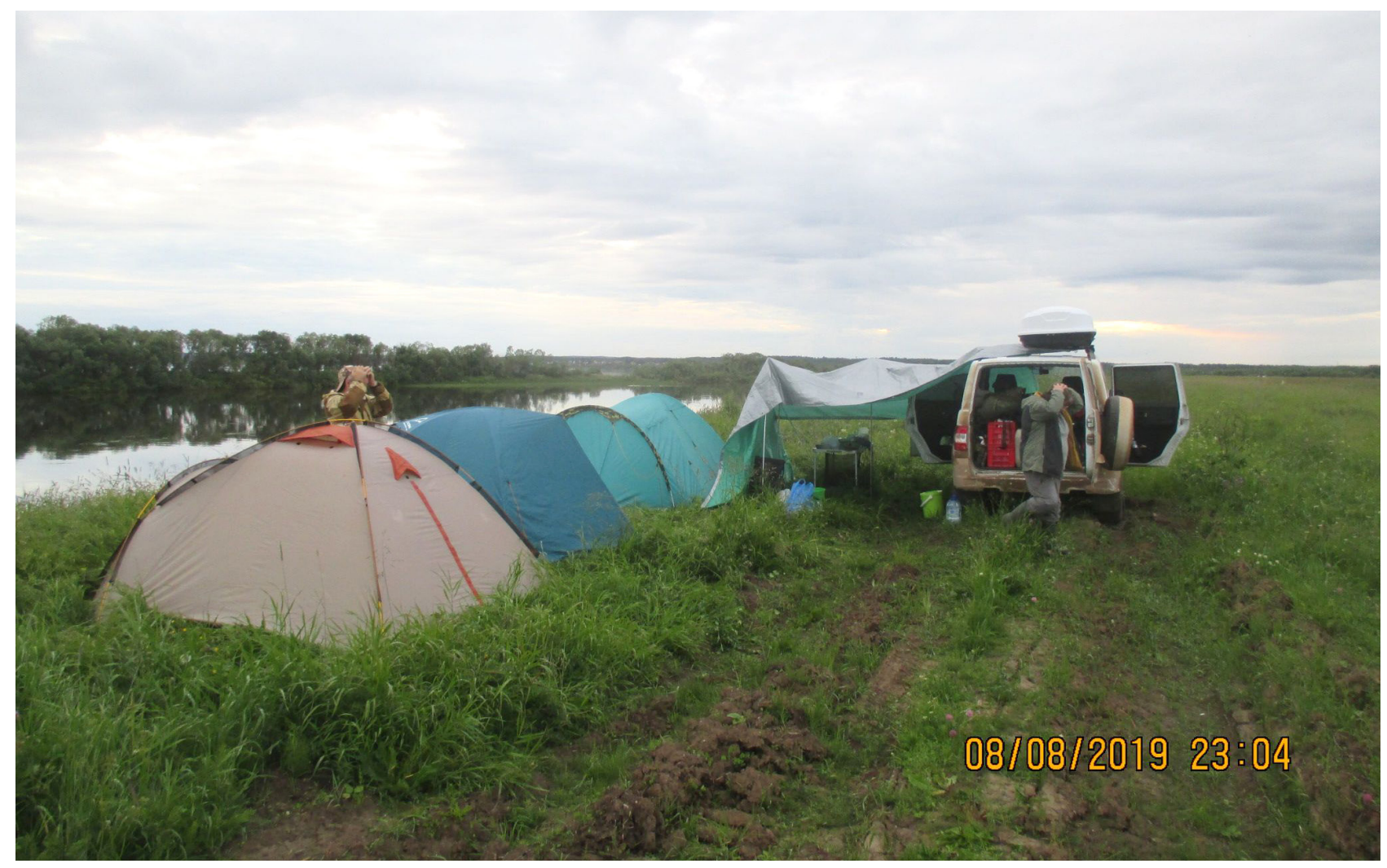

Рис. 2. Типичный экспедиционный лагерь на одну ночь

Fig. 2. Typical one night expedition camp

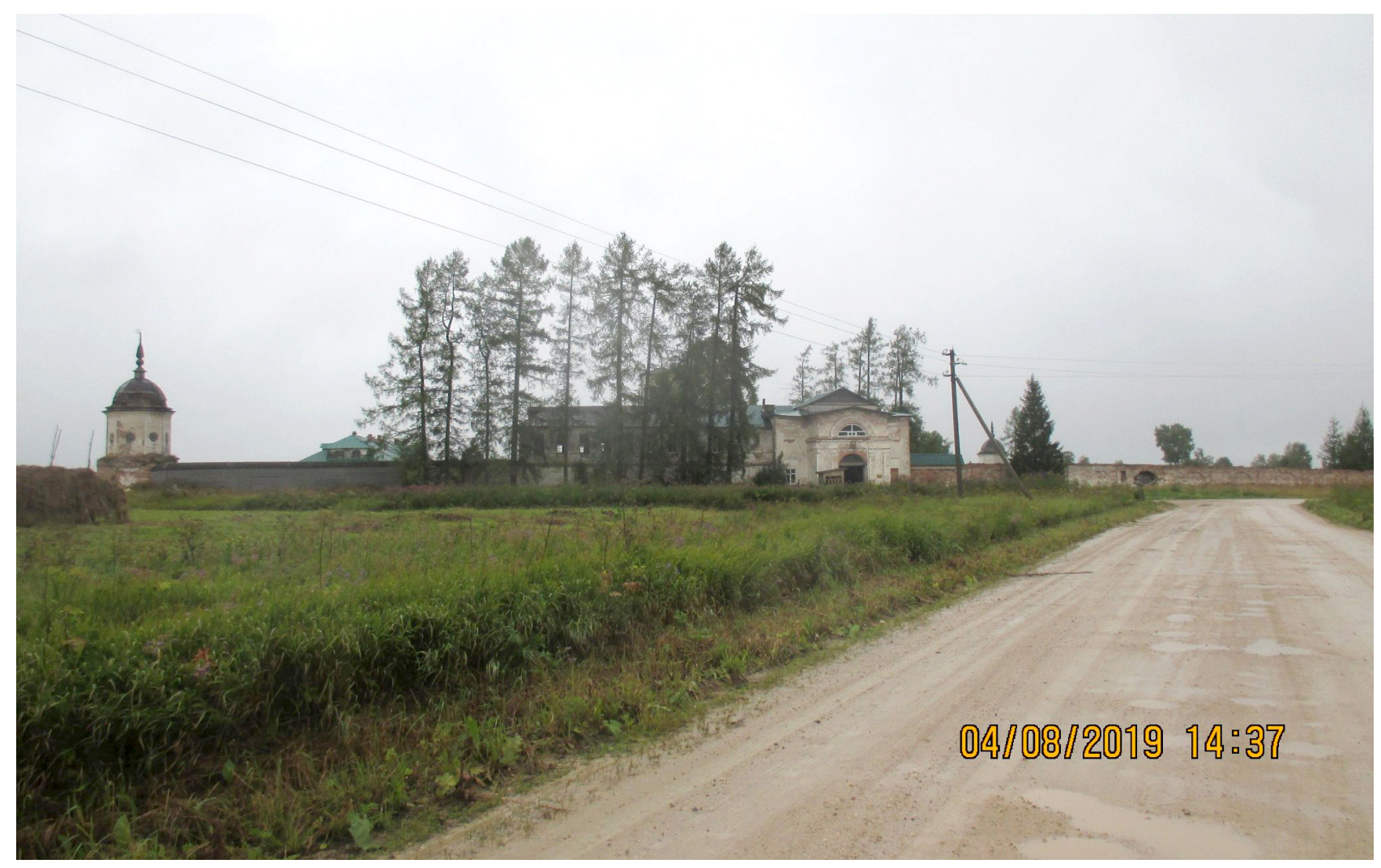

Рис. 3. На подъезде к Александро-Ошевенскому монастырю

Fig. 3. At the entrance to Alexandro-Oshevensky monastery 


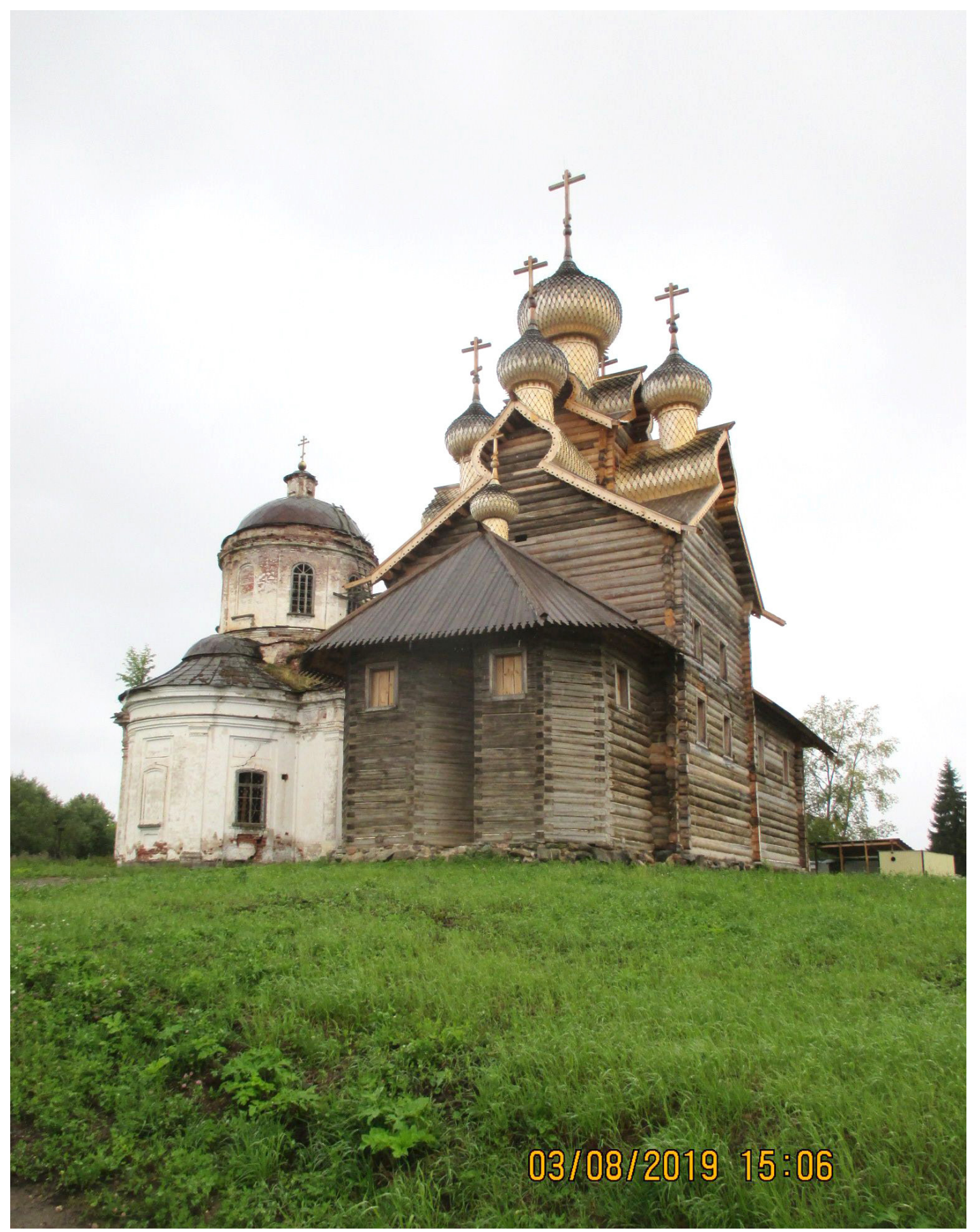

Рис. 4. Одна из многочисленных деревянных церквей Русского Севера Fig. 4. One of the many wooden churches of the Russian North

разрастания и с сохранением микробиома нами разработан «гербарный» метод сохранения. В пакет из крафт-бумаги помещали 20-30 мл жидкой закваски (рис. 5), обкладывали пакет хорошо впитывающей влагу бумагой и оставляли под небольшим прессом на передней панели в салоне автомобиля. Этим способом в течение 8-10 ч даже при высокой влажности образовывался консолидированный сыпучий продукт, который ножом легко удаляли с внутренней поверхности бумажного пакета и переносили в емкости. Так были получены пять из шести привезенных образцов.

\section{Заключение}

Ведение закваски и получение хлеба на закваске - трудоемкий технологический процесс, поэтому в наше время реализуется в населенных пунктах или монастырях только в случае наличия "рынка сбыта» - не менее 50-100 потребителей продукции на закваске. Как правило, хлебопечением с использованием закваски занимаются деревенские или поселковые пекарни или подворья более-менее крупных (населенных) монастырей. Чаще всего в местах проведения экспедиции используется именно ржаная закваска - види- 


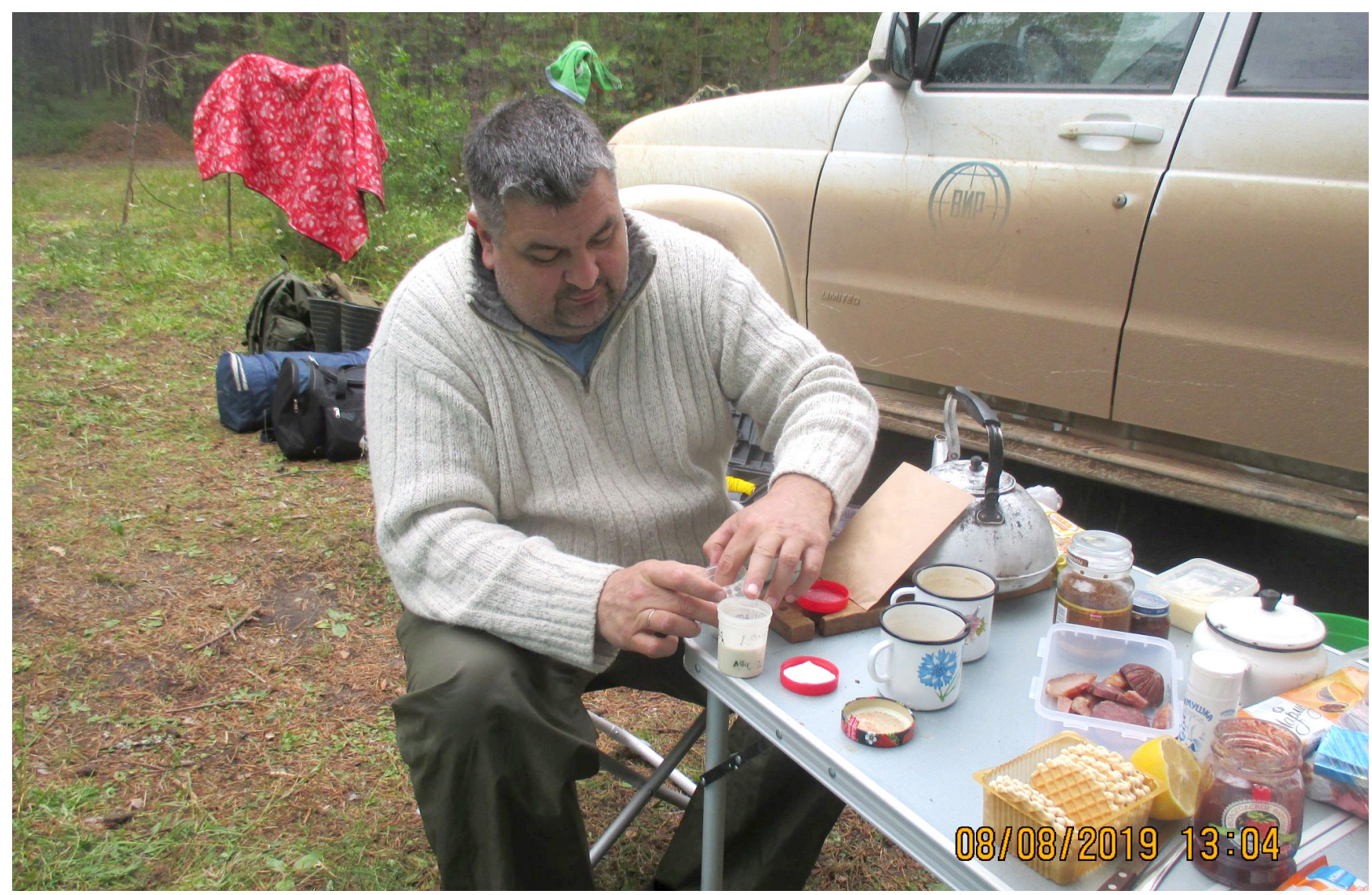

Рис. 5. Подготовка образца закваски к высушиванию

Fig. 5. Preparation of a sample of sourdough culture for drying

мо, это следствие сложившихся местных традиций и вкусовых предпочтений. В ходе экспедиции нами был разработан походный метод сохранения образцов закваски при помощи высушивания жидкой закваски между листов бумаги, по принципу гербария. Собрано четыре образца ржаной закваски и два - пшеничной.

\section{Список литературы/References}

Афанасьева О.В. Использование стартовых культур молочнокислых бактерий и дрожжей. В кн.: Микробиология хлебопекарного производства / Санкт-Петербургский филиал научно-исследовательского института хлебопекарной промышленности. СПб.: Береста, 2003. 221 с.

[Afanas'eva O.V. Application of lactic acid bacteria and yeasts starting cultures. In: Microbiology of baking industry / Saint-Petersburg Brunch of the Scientific Research Institute for the Baking Industry. StPetersburg: Beresta, 2003. 221 p. (in Russian)]

Афанасьева О.В., Кузнецова Л.И., Павловская Е.Н., Савкина О.А. Биологическая хлебная закваска - путь к повышению конкурентоспособности хлебобулочных изделий с использованием ржаной муки. Хлебопечение России. 2009;6: 18-19.

[Afanas'eva O.V., Kuznetsova L.I., Pavlovskaya E.N., Savkina O.A. Biological bread sourdough - a way to increase the competitiveness of baked goods using rye flour. Bakery Russia. 2009;6:18-19. (in Russian)]
Карельская С. Хлебные закваски. Хлебопечение/Кондитерская сфера. 2015;1(58):36-37.

[Karelskaya S. Bread sourdough. Bakery/Confectionary. 2015;1(58):3637. (in Russian)]

Локачук М.Н., Павловская Е.Н., Савкина О.А., Хлесткин В.К. Исследование микрофлоры спонтанных заквасок для хлебопекарного производства из географически отдаленных мест Северо-Западного региона России. Хлебопечение России. 2019;3:35-38.

[Lokachuk M.N., Pavlovskaya E.N., Savkina O.A., Khlestkin V.K. The study of microflora of spontaneous starter cultures for baking production from geographically remote places of the North-West region of Russia. Bakery Russia. 2019;3:35-38. (in Russian)]

Сборник современных технологий хлебобулочных изделий / Под общ. ред. А.П. Косована. М.: Московская типография № 2, 2008. $271 \mathrm{c}$.

[Collection of modern technologies of bakery products / Under the general editorship of A.P. Kosovan. Moscow: Moscow typography No. 2, 2008. 271 p. (in Russian)]

Sieuwerts S., Bron P.A., Smid E.J. Mutually stimulating interactions between lactic acid bacteria and Saccharomyces cerevisiae in sourdough fermentation. LWT - Food Sci Technol. 2018;90:201-206. https://doi.org/10.1016/j.lwt.2017.12.022.

Viiard E., Bessmeltseva M., Simm J., Talve T., Aaspõllu A., Paalme T., Sarand I. Diversity and Stability of Lactic Acid Bacteria in Rye Sourdoughs of Four Bakeries with Different Propagation Parameters. PLOS ONE. 2016;11(2): e0148325. https://doi.org/10.1371/journal. pone. 0148325

Конфликт интересов. Автор заявляет об отсутствии конфликта интересов.

Поступила в редакцию 03.02.2020. После рецензирования 24.03.2020. Принята к публикации 24.03.2020. Oпубликована Online-first 10.04.2020 